\title{
Acknowledgments and Spelling Conventions
}

As brief as it is, this book has a long history. I took my first notes for it in Paris at the Archives du Quai d'Orsay in 1982 [sic], while researching another subject. The notes went into a drawer for several years. I worked on the Brazilian sailors' revolt at moments snatched from other concerns over the following decades, when I happened to be in Rio de Janeiro, Lisbon, Washington, or London. The project became a kind of hobby, a word I prefer to "obsession." As the years went by, new materials became available and relevant new studies appeared. Even now, however, neither I nor other historians working on the revolt have explored all the relevant sources. Among other things, the reactions of the German and Argentine governments have yet to be adequately examined. In any event, like all researchers, I became indebted to a number of persons and institutions who helped me realize this project, minus the customary acknowledgment of foundation support that usually figures in such lists. Among those who helped me were fellow scholars interested in the revolt itself-Álvaro Pereira de Nascimento, Sílvia Capanema de Almeida, Zachary Morgan, Marco Morel, and Admiral Hélio Leôncio Martins. Others who assisted me at various times were two former students, Bert Barickman and Zephyr Frank, now colleagues. Dain Borges and Jeffrey Needell greatly improved the manuscript, whatever its present merits, by writing thorough critiques as anonymous readers. Michael Hall unfailingly offered good advice on sources and repositories. My research assistant, Noah Lenstra, helped me to organize the endnotes; he also standardized spelling and ordered the bibliographical materials, as well as combing through documents and using his skills in drawing maps and enhancing the quality of photographs. 
I am grateful to the personnel of the following institutions that provided archival materials, published sources, cartoons, and photos: in Brazil, the Arquivo Nacional, the Biblioteca Nacional, the Arquivo da Marinha, the Museu da Imagem e do Som, the Arquivo Geral da Cidade do Rio de Janeiro, the Arquivo Público do Estado do Rio de Janeiro, the Asociação Brasileira da Imprensa, and the Casa Rui Barbosa (all in Rio), the Biblioteca Mário de Andrade in Sao Paulo, and the Arquivo Público do Estado do Rio Grande do Sul in Porto Alegre; in the United States, the National Archives and Records Administration in Washington, DC, and the Library of the University of Illinois in Urbana; in Britain, the National Archives in London; in France, the Archives Diplomatiques du Quai d'Orsay in Paris; and in Portugal, the Arquivo do Ministério de Negócios Estrangeiros in Lisbon.

Brazilian Portuguese orthography has undergone several reforms since the period studied here, and I have followed the widely accepted practice of using modern spelling in the text and original spelling in the list of works cited. The original orthography will be useful for students and scholars who want to check the sources I used. 